\title{
LA-ICP-MS zircon U-Pb ages of felsic tuffaceous beds in the Takikubo and Horita formations, Izumi Group, Ikeda district, eastern Shikoku, southwestern Japan
}

\author{
NODA Atsushi ${ }^{1,{ }^{*}}$, DANHARA Tohru ${ }^{2}$, IWANO Hideki ${ }^{2}$ and HIRATA Takafumi ${ }^{3}$
}

\begin{abstract}
Noda Atsushi, Danhara Tohru, Iwano Hideki and Hirata Takafumi (2020) LA-ICP-MS U-Pb ages of felsic tuffaceous beds in the Takikubo and Horita formations, Izumi Group, Ikeda district, eastern Shikoku, southwestern Japan. Bulletin of the Geological Survey of Japan, vol. 71 (1), p. 33-48, 7 figs, 5 tables.
\end{abstract}

\begin{abstract}
Laser ablation-inductively coupled plasma-mass spectrometry zircon U-Pb ages were acquired for three felsic tuffaceous beds, one from the upper Takikubo Formation (sample IT01) and two from the lower Horita Formation (IT02 and IT03), to determine depositional ages of the Izumi Group in the Ikeda district, eastern Shikoku, southwestern Japan. The weighted mean ${ }^{206} \mathrm{~Pb} /{ }^{238} \mathrm{U}$ ages and $2 \sigma$ errors are 78.3 $\pm 1.3 \mathrm{Ma}$ (IT01), $80.8 \pm 1.2 \mathrm{Ma}$ (IT02), and $79.3 \pm 1.1 \mathrm{Ma}$ (IT03). Two of the three ages $(78.3 \pm 1.3$ Ma and $79.3 \pm 1.1 \mathrm{Ma})$ passed the $\chi_{\text {red }}^{2}$ (reduced) statistical test, but the other $(80.8 \pm 1.2 \mathrm{Ma})$ failed. These U-Pb ages indicate that the maximum depositional age of the Izumi Group in this district is middle Campanian (magnetostratigraphic chron C33n). These ages are similar to those reported from the lower Takikubo Formation in the Kan-onji district (80.8-78.3 Ma). Although an apparent stratigraphic thickness from the lower Takikubo Formation to the lower Horita Formation reaches $12 \mathrm{~km}$, there is no younging trend of the zircon $\mathrm{U}-\mathrm{Pb}$ ages through these formations. This suggests that either the sedimentation rate of the Izumi Group was high or there was a lack of volcanic activity that could produce new zircon crystals in the hinterland during deposition of the succession.
\end{abstract}

Keywords: Campanian, Cretaceous, Felsic tuff, Izumi Group, Shikoku, Takikubo Formation, Horita Formation, $\mathrm{U}-\mathrm{Pb}$ age, Zircon

\section{Introduction}

The Izumi Group (Matsumoto, 1954) consists of shallowto deep-marine deposits that are distributed in a 10-20-kmwide and 300-km-long zone along the northern side of the Median Tectonic Line, from western Shikoku to the Kii Peninsula, southwestern Japan (Fig. 1). Paleontological evidence, including macro-fossils (ammonoids and inoceramids) and micro-fossils (radiolarian assemblages), indicates that the depositional age of the Izumi Group is Campanian-Maastrichtian (Late Cretaceous) and that it youngs toward the east (Suyari, 1973; Bando and Hashimoto, 1984; Yamasaki, 1987; Hashimoto et al., 2015). Although a few studies have reported occurrences of macrofossils from the Izumi Group in the Ikeda district, eastern Shikoku, their age resolution is inadequate to discuss details of the depositional ages of the Izumi Group. In addition, radiometric age data from the Izumi Group in eastern Shikoku are sparse; until now, only two ages have been reported from eastern Shikoku (Noda et al., 2017b). Therefore, further radiometric age data were required to constrain detailed depositional ages and the sedimentation rate of the strata. This paper reports new laser ablation-inductively coupled plasma-mass spectrometry (LA-ICP-MS) U-Pb ages of detrital zircons in felsic tuff beds, including one sample from the Takikubo Formation and two samples from the Horita Formation of the Izumi Group, in the Ikeda district, eastern Shikoku.

\section{Geological background}

The Izumi Group in eastern Shikoku is composed of a main facies and a northern marginal facies (Matsuura et $a l .$, 2002). The main facies comprises alternating beds of sandstone and mudstone and is divided into four formations: the Takikubo, Horita, Higaidani, and Bandodani formations, from the lowermost (west) to uppermost (east) (Yamasaki, 1986). The northern marginal facies consists of two formations: the Shiroyama Formation (conglomerate and sandstone) and the Hiketa Formation (massive mudstone).

\footnotetext{
${ }^{1}$ AIST, Geological Survey of Japan, Research Institute of Geology and Geoinformation

${ }^{2}$ Kyoto Fission-Track Co., Ltd., 44-4 Minamitajin-cho, Omiya, Kita-ku, Kyoto 603-8832. Japan

${ }^{3}$ Geochemical Research Center, Graduate School of Science, The University of Tokyo, 7-3-1 Hongo, Bunkyo-ku, Tokyo 113-0033, Japan

*Corresponding author: NODA, A., Central 7,1-1-1 Higashi, Tsukuba, Ibaraki 305-8567, Japan. Email:a.noda@aist.go.jp
} 


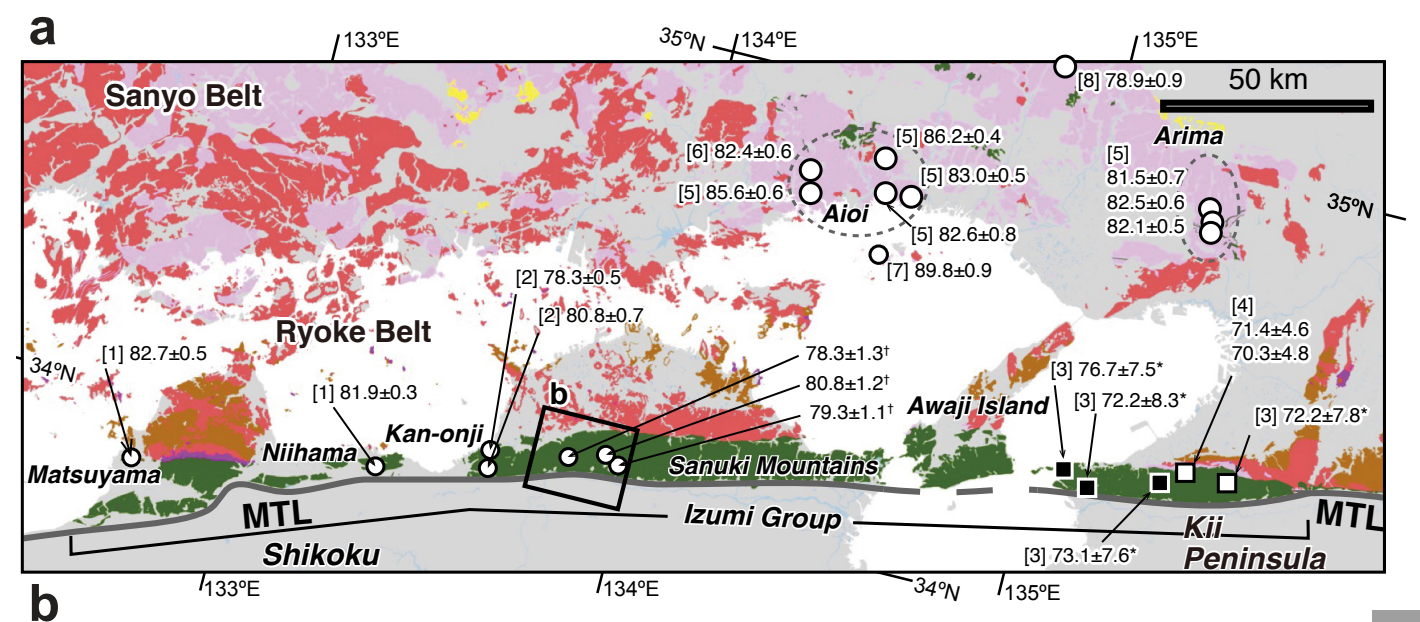

Early Cretaceous
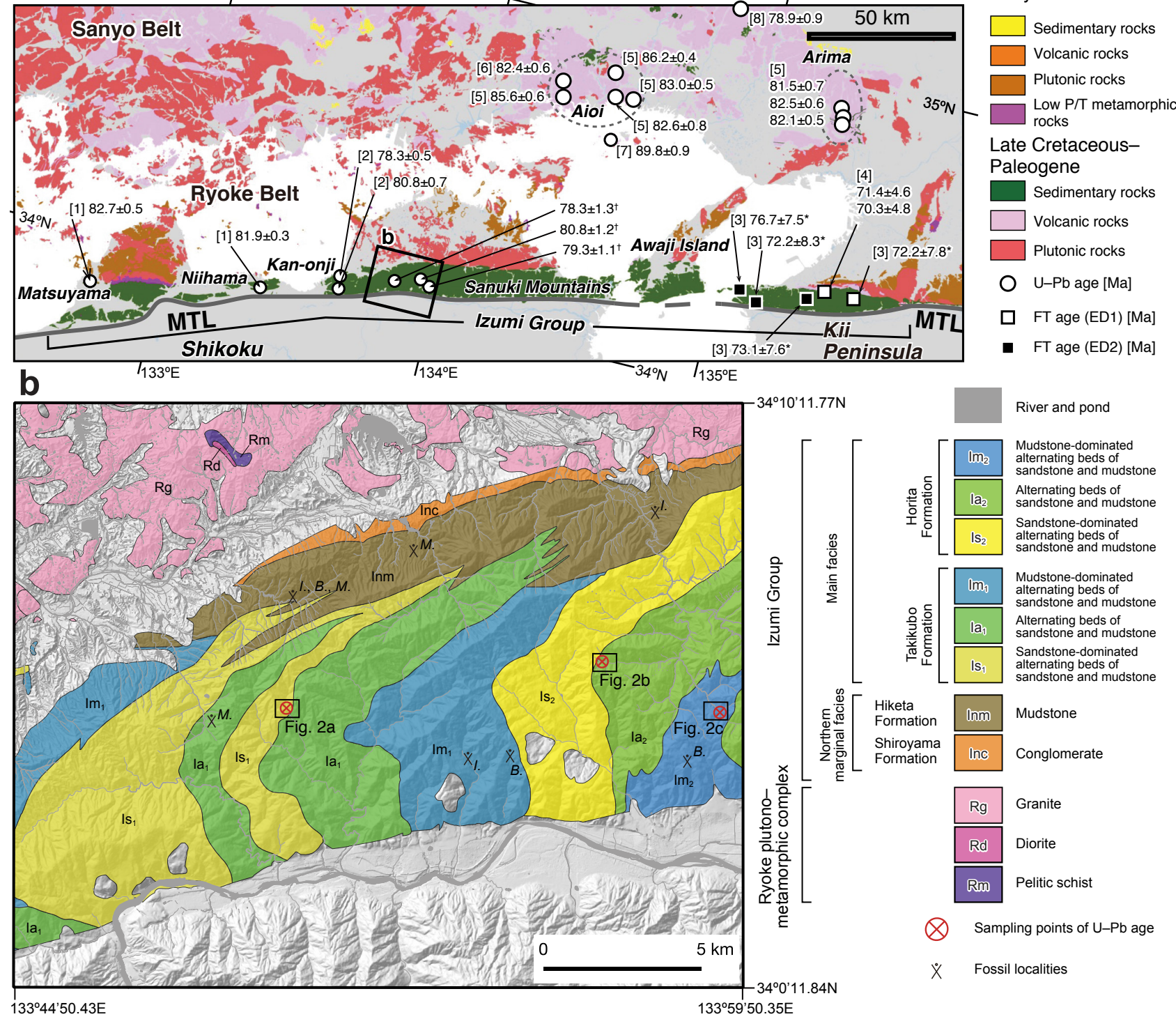

River and pond

Mudstone-dominated alternating beds of sandstone and mudston Alternating beds of sandstone and mudston Sandstone-dominated
alternating beds of sandstone and mudstone Mudstone-dominated alternating beds of sandstone and mudstone Alternating beds of sandstone and mudstone Sandstone-dominated alternating beds of
sandstone and mudston

$133^{\circ} 44^{\prime} 50.43 \mathrm{E}$ $133^{\circ} 59^{\prime} 50.35 \mathrm{E}$

Fig. 1 (a) Overview map showing the locations of previously reported U-Pb and fission-track (FT) ages (2 $\sigma)$. FT ages include data obtained using the external-detector method using internal surfaces (ED1) and external surfaces (ED2). The geological map is reproduced from the Seamless Digital Geological Map of Japan (Geological Survey of Japan, AIST, 2015). The inclined square shows the Ikeda district. MTL = Median Tectonic Line. References: [1] Noda and Sato (2018), [2] Noda et al. (2017b), [3] Miyata (2004), [4] Seike et al. (2013), [5] Sato et al. (2016b), [6] Sato et al. (2016a), [7] Sato (2016), and [8] Sato (2015). Asterisks (*) denote FT ages recalculated from the original data using a decay constant of $D=1.55125 \times$ $10^{-10} \mathrm{yr}^{-1}$ instead of $1.480 \times 10^{-10} \mathrm{yr}^{-1}$. Daggers $(\dagger)$ indicate U-Pb ages from this study. Modified from Noda and Sato (2018). (b) Locations of felsic tuff samples collected for U-Pb age determinations. The geological map is from the Geological Survey of Japan, AIST (2015). The shaded topography is based on GSI Maps (http://maps.gsi.go.jp/). Abbreviations of fossil localities: M., Metaplacenticeras subtilistriatum; B., Baculites sp.; I., Inoceramus balticus.

A series of studies in the 1960 s and 1970s identified the following features of the Izumi Group: (1) the strata young from west to east; (2) the paleocurrent directions in the main facies are largely from east to west, opposite to the younging direction; and (3) the northern marginal facies interfingers the main facies (Suyari, 1966; Suyari et al., 1968; Suyari, 1973).

The Ikeda district contains the lower two formations of the main facies, the Takikubo and Horita formations, and the northern marginal facies, the Shiroyama and Hiketa formations (Fig. 1). Both the Takikubo and the Horita formations are dominated by alternating beds of sandstone and mudstone, but the proportion of sandstone to mudstone changes within the formation. The lower part of the Takikubo Formation in the Kan-onji district, which is situated at the west of the Ikeda district, is subdivided 
Table 1 A list of analyzed samples. Longitude and latitude are given in the WGS84 datum.

\begin{tabular}{cccccccc}
\hline Sample no. & ID & Longitude & Latitude & Date & Loc no. & Lithology & GSJ reg. no. \\
\hline \hline IT01 & 2469 & $133^{\circ} 50^{\prime} 26.9^{\prime \prime E}$ & $34^{\circ} 4^{\prime} 58.8^{\prime \prime} \mathrm{N}$ & $2016-11-11$ & 01 & Felsic tuffaceous sandstone & R109880 \\
IT02 & 6326 & $133^{\circ} 56^{\prime} 56.4^{\prime \prime E}$ & $34^{\circ} 5^{\prime} 46.3 " \mathrm{~N}$ & $2017-12-09$ & 02 & Felsic tuff & R109881 \\
IT03 & 2368 & $133^{\circ} 59^{\prime} 21.8^{\prime \prime} \mathrm{E}$ & $34^{\circ} 4^{\prime} 54.1^{\prime \prime} \mathrm{N}$ & $2016-11-10$ & 03 & Felsic tuffaceous sandstone & R109882 \\
\hline
\end{tabular}

into the Minoura Sandstone and Mudstone Member, Tanono Sandstone Member, Ebisukui Mudstone Member, and Umpenji Sandstone Member as the stratigraphic order based on the dominant lithology (Noda et al., 2017a). However, upper part of the Takikubo and the Horita formations have not yet been subdivided into members.

The depositional environments for the Izumi Group are thought to have been a line-sourced slope or fan delta in the marginal facies and a point-sourced submarine fan in the main facies (Nishiura et al., 1993; Tanaka, 1993; Tanaka and Maejima, 1995; Noda and Toshimitsu, 2009). Sandstone in the Izumi Group is mostly lithic, although some is quartzo-feldspathic (Nishimura, 1976). The chemical compositions of heavy minerals (garnet and spinel) in the sandstone indicate that their source was the granitic and metamorphic rocks exposed in the Ryoke and Sanyo belts (Yokoyama and Goto, 2000).

Yamasaki (1987) and Hashimoto et al. (2015) identified several radiolarian fossil zones in the Izumi Group, and the upper Takikubo Formation together with the Horita Formation correspond to the Archaeodictyomitra lamellicostata Zone. Several macro-fossils have been reported in this district (Fig. 1), and ammonite fossils characterized by Metaplacenticeras subtilistriatum have been found in the adjacent Hiketa Formation (Bando and Hashimoto, 1984). A few occurrences of Baculites sp. have been recognized in the upper Takikubo Formation (Ishida et al., 1993) and the lower Horita Formation (Hashimoto et al., 2003). Some occurrences of Inoceramus balticus are also reported in the Hiketa Formation and the upper Takikubo Formation (Nakano, 1953; Bando and Hashimoto, 1984). These fossils indicate that the Izumi Group in this district is the lower part of the upper Campanian.

\section{Samples and methods}

\subsection{Samples}

One sample (IT01) from the upper Takikubo Formation and two samples (IT02 and IT03) from the lower Horita Formation were collected from the Ikeda district, in the central Sanuki Mountains, eastern Shikoku (Fig. 1 and Table 1).

The sampling locality of IT01 is situated within the sandstone-dominated sequence of the Umpenji Sandstone Member (Noda et al., 2017a) of the Takikubo Formation (Fig. 2a). IT01 was collected from a medium-bedded fine- to medium-grained light-gray felsic tuffaceous sandstone (Fig. 3a). The tuffaceous sandstone constitutes a 3-m-thick tuffaceous unit. The sandstone shows weak parallel laminations, and flattened pumice clasts $(<6 \mathrm{~mm}$ in length) and plagioclase crystals ( $<1 \mathrm{~mm}$ in length) are common. Under the microscope, it is classified as a vitriccrystal tuff containing flattened glass shards (pumice) and quartz and plagioclase crystals (Fig. 3b). The matrix has a felsitic texture.

IT02 was collected from a felsic tuff bed in the basal sandstone-dominated succession of the Horita Formation (Fig. 2b). The total thickness of the felsic tuff bed is $<20$ $\mathrm{m}$, and it is composed of medium- to thickly bedded felsic tuff (Fig. 3c). The sample is a light-gray fine-grained medium-bedded vitric tuff with parallel laminations. Bubble-wall glass shards dominate, with a few crystals and lithic fragments being observed under the microscope (Fig. 3d).

IT03 was collected from a fine-grained, thick-bedded tuffaceous sandstone which was intercalated within the mudstone-dominated facies of the Horita Formation (Fig. 2c). The tuffaceous sandstones constitute more than 30-m-thick tuffaceous unit with thinly to medium-bedded dark-gray mudstone (Fig. 3e). The sample is a vitriccrystal-lithic tuff containing embayed quartz and felsic volcanic rock fragments with bubble-wall glass shards (Fig. 3f).

\subsection{Methods}

Zircon grains were separated from the samples by crushing, sieving, panning, magnetic, and heavy liquid (sodium polytungstate) techniques, and then mounted on a PFA Teflon sheet. U-Pb dating was performed using the LA-ICP-MS system installed in the Geochemical Research Center, Graduate School of Science, The University of Tokyo, Japan. The LA-ICP-MS system consisted of an ICP-MS instrument (iCAP Qc, Thermo Fisher Scientific, Waltham, MA, USA) and a femtosecond LA instrument (IFRIT Type-C, Cyber Laser Inc., Tokyo, Japan). The operating conditions for the LA and ICP-MS instruments are summarized in Table 2. The laser had a wavelength of $260 \mathrm{~nm}$, an energy of $2-3 \mathrm{~J} / \mathrm{cm}^{2}$, a spot size of $15 \mu \mathrm{m}$ (IT01 and IT03) or $10 \mu \mathrm{m}$ (IT02), and a repetition rate of $15 \mathrm{~Hz}$ (IT01 and IT03) or $10 \mathrm{~Hz}$ (IT02). Helium was used as the carrier gas inside the ablation cell and was mixed with argon before entering the ICP-MS. Signal intensities for ${ }^{202} \mathrm{Hg},{ }^{204}(\mathrm{~Pb}+\mathrm{Hg}),{ }^{206} \mathrm{~Pb},{ }^{207} \mathrm{~Pb},{ }^{208} \mathrm{~Pb}$, ${ }^{232} \mathrm{Th}$, and ${ }^{238} \mathrm{U}$ were obtained from 30 zircon crystals in each sample.

The contribution of common $\mathrm{Pb}$ was monitored using the ${ }^{204} \mathrm{~Pb}$ signal with ${ }^{204} \mathrm{Hg}$ as an isobaric interference. The 


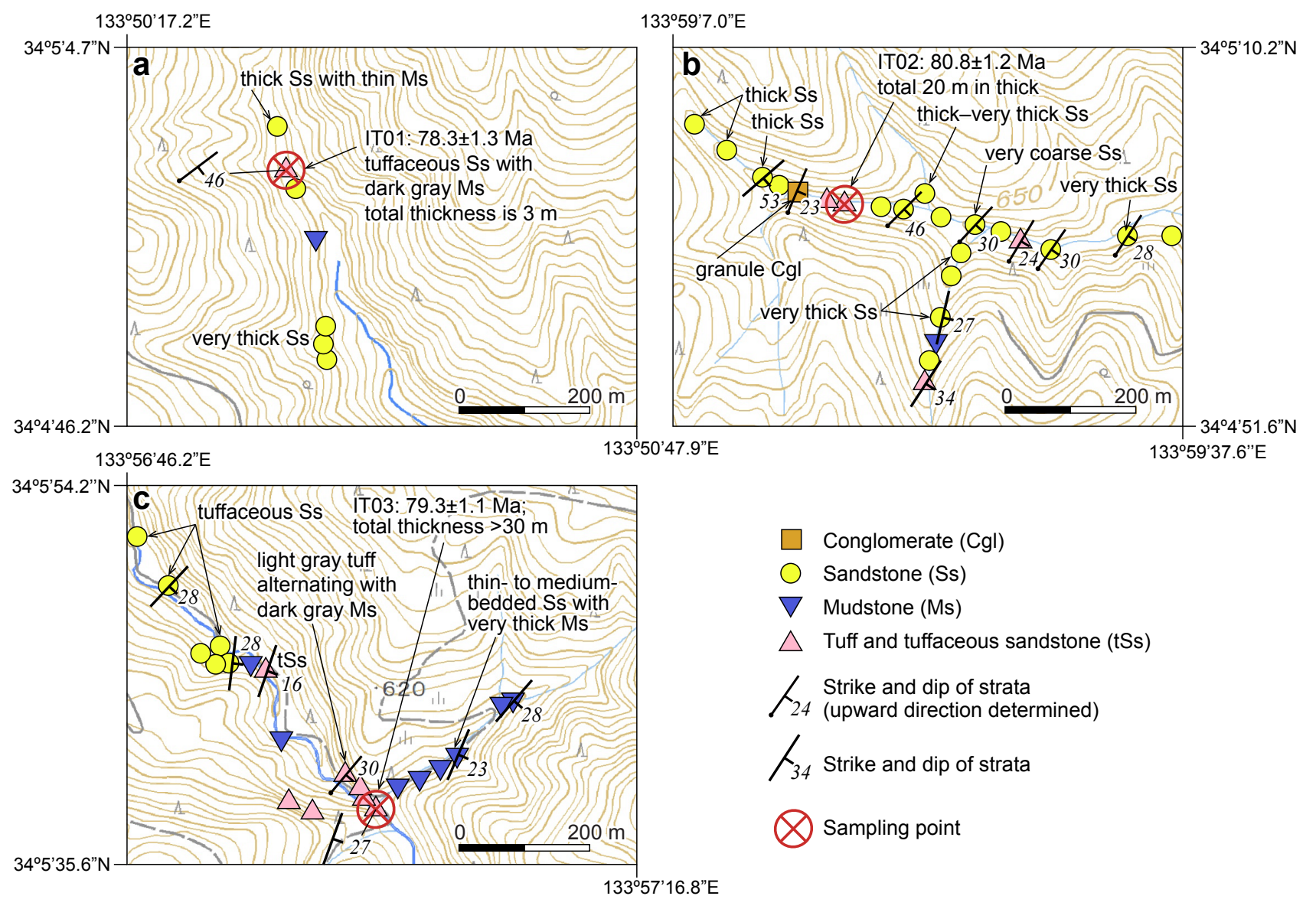

Fig. 2 Locations of sampling points of (a) IT01, (b) IT02, and (c) IT03. The topographic maps are based on GSI Maps (http://maps.gsi.go.jp/).

abundance of ${ }^{204} \mathrm{Hg}$ was calculated from blank-corrected ${ }^{202} \mathrm{Hg}$ on the basis of the natural ${ }^{202} \mathrm{Hg} /{ }^{204} \mathrm{Hg}$ ratio, which in turn was subtracted from the total 204 signal to yield ${ }^{204} \mathrm{~Pb}$. We applied one-shot cleaning on the sample surfaces before the analysis to reduce the risk of common- $\mathrm{Pb}$ contamination. Instrumental bias in the ${ }^{206} \mathrm{~Pb}^{*} / 238 \mathrm{U}$ ratio (asterisk denotes radiogenic) was corrected using 91500 zircon (Wiedenbeck et al., 1995) as a primary standard, and OD-3 (Iwano et al., 2012, 2013), GJ-1(Jackson et al., 2004), and Plešovice (Sláma et al., 2008) zircons as secondary standards (Tables 3-5).

The resultant $\mathrm{U}-\mathrm{Pb}$ isotopic ratios and errors were used to plot concordia diagrams and histograms using UPbplot.py version 0.0.9 (Noda, 2017). The latest version of this software can be downloaded from the website (https://github.com/anoda/UPbplot.py). Discordance was calculated using the following equation:

$$
\text { Discordance }=\left(1-\frac{{ }^{206} \mathrm{~Pb}^{*} /{ }^{238} \mathrm{U} \text { age }}{{ }^{207} \mathrm{~Pb}^{*} /{ }^{235} \mathrm{U} \text { age }}\right) \times 100
$$

We excluded data whose discordance exceeded $20 \%$ from the age calculations. We then applied the generalized ESD (extreme Studentized deviate) test to exclude outliers (Rosner, 1983). Details of this test are described in the Appendix. We also calculated reduced chi-squared statistics ( $\chi_{\text {red; }}^{2}$ Spencer et al., 2016). If $\chi_{\text {red }}^{2}$ for the uncertainties and weighted mean of the observed data do not fall inside of the range of $1 \pm 2 \sqrt{2 / f}$, where $f$ is the degrees of freedom $(n-1)$, the hypothesis that the weighted mean represents the depositional age of the observed data set is rejected with a probability of $>95 \% . \chi_{\text {red }}^{2}$ is equivalent to the mean square weighted deviation (MSWD; Wendt and Carl, 1991). For the case of $\chi_{\text {red }}^{2}>1+2 \sqrt{2 / f}$, the assumed analytical errors of the measurement are too small, or the data are not sampled from a single statistical population, that is, there is a mixing of multiple populations. In contrast, $\chi_{\text {red }}^{2}<1-2 \sqrt{2 / f}$ indicates that the grains could be derived from a single population but the analytical uncertainties are overestimated.

\section{Results}

We analyzed 30 zircon grains in each sample. The ${ }^{206} \mathrm{~Pb} /{ }^{238} \mathrm{U},{ }^{207} \mathrm{~Pb} /{ }^{235} \mathrm{U}$, and ${ }^{207} \mathrm{~Pb} /{ }^{206} \mathrm{~Pb}$ ages of zircons were calculated using the measured isotopic ratios and decay constants. 

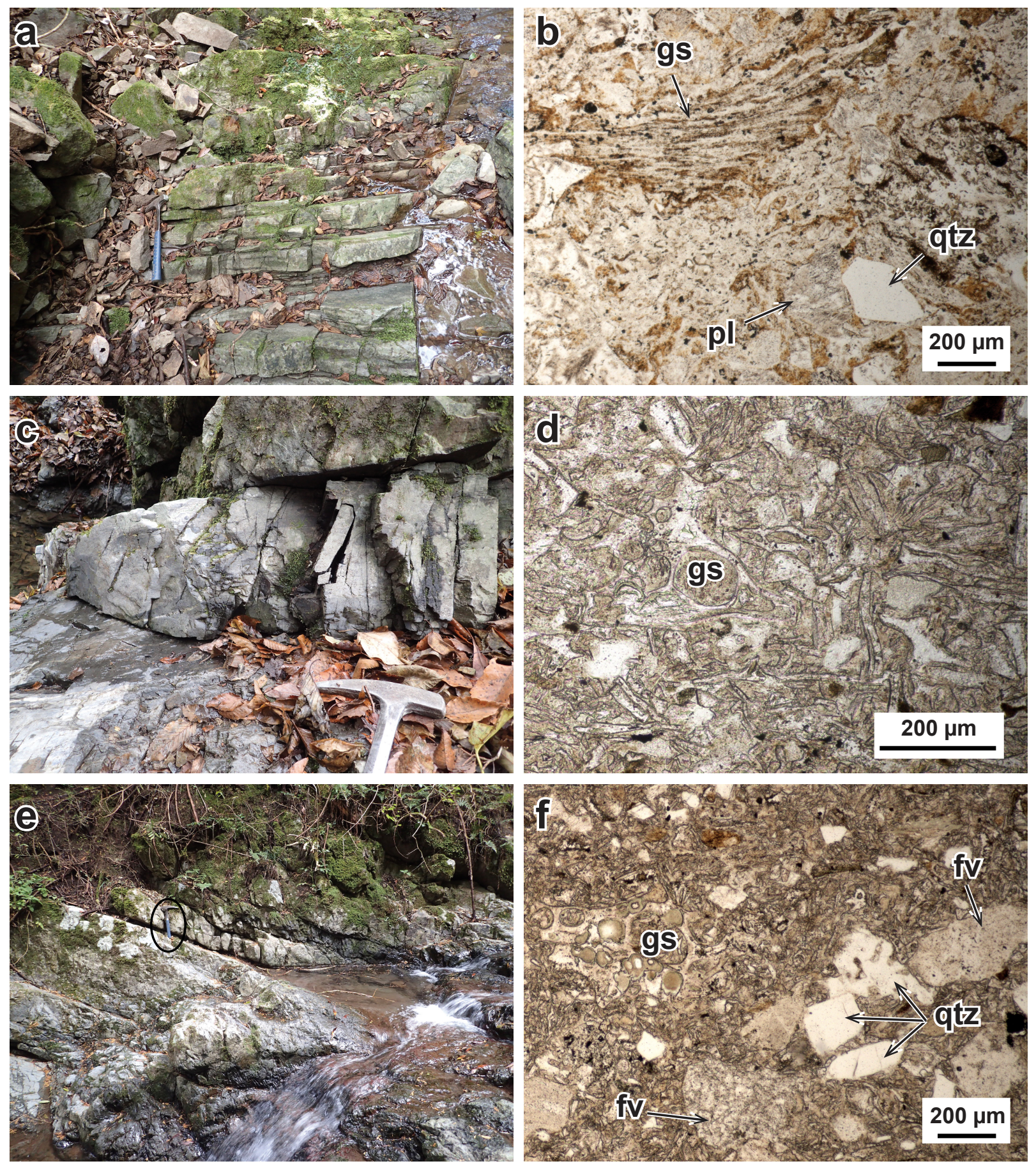

Fig. 3 (a) Photograph of an outcrop of the felsic tuff bed from which sample IT01 was obtained, showing a 3 -m-thick tuff bed containing repetitions of thin- to medium-bedded tuff. The hammer is $33 \mathrm{~cm}$ in length. Munegi, Higashiyama, Higashimiyoshi Town, Miyoshi County, Tokushima Prefecture. (b) Photomicrograph of IT01 (plane-polarized light). (c) Photograph of the outcrop from which sample IT02 was obtained. The hammer head is $18 \mathrm{~cm}$ long. Shimobuke, Katsuura, Manno Town, Nakatado County, Kagawa Prefecture. (d) Photomicrograph of IT02 (plane-polarized light). Fragments of glass shards dominate. (e) Photograph of the outcrop from which sample IT03 was obtained. A circle indicates location of a hammer as a scale, whose length is $33 \mathrm{~cm}$. Hachimine, Katsuura, Manno Town, Nakatado County, Kagawa Prefecture. (f) Photomicrograph of IT03 (plane-polarized light). Abbreviations: gs, glass shards; qtz, quartz; pl, plagioclase; $\mathrm{fv}$, felsic volcanic rock fragments. 
Table 2 ICP-MS and laser operating conditions and data acquisition parameters.

\begin{tabular}{|c|c|}
\hline Parameters & Value/Description \\
\hline \multicolumn{2}{|l|}{$\overline{\text { Laser ablation }}$} \\
\hline Model & $\begin{array}{l}\text { IFRIT (Cyber Laser Inc., Tokyo, } \\
\text { Japan) }\end{array}$ \\
\hline Laser type & Type-C Ti:S femtosecond laser \\
\hline Laser wave length & $260 \mathrm{~nm}(\mathrm{THG})$ \\
\hline Laser energy & $2-3 \mathrm{~J} / \mathrm{cm}^{2}$ \\
\hline Pulse width & $230 \mathrm{fs}$ \\
\hline Ablation crater size & $\begin{array}{l}10 \mu \mathrm{m} \text { (IT02) } \\
15 \mu \mathrm{m} \text { (IT01 \& IT03) }\end{array}$ \\
\hline Repetition rate & $\begin{array}{l}10 \mathrm{~Hz}(\text { IT02) } \\
20 \mathrm{~Hz}(\text { IT01 \& IT03) }\end{array}$ \\
\hline Carrier gas (flow rate) & $\mathrm{He}(0.60-0.83 \mathrm{~L} / \mathrm{min})$ \\
\hline \multicolumn{2}{|l|}{ ICP-MS } \\
\hline Model & $\begin{array}{l}\text { iCAP-Qc (Thermo Fisher } \\
\text { Scientific, Waltham, MA, USA) }\end{array}$ \\
\hline ICP-MS type & Quadrupole \\
\hline Forward power & $1400 \mathrm{~W}$ \\
\hline Carrier gas (flow rate) & $\operatorname{Ar}(0.90-1.10 \mathrm{~L} / \mathrm{min})$ \\
\hline Scanning mode & Standard mode \\
\hline Data acquisition protocol & $50 \mathrm{~s}$ ( $15 \mathrm{~s}$ gas blank, $35 \mathrm{~s}$ ablation) \\
\hline Analysis mode & Time-resolved analysis \\
\hline Monitor isotopes & $\begin{array}{l}{ }^{202} \mathrm{Hg},{ }^{204}(\mathrm{Hg}+\mathrm{Pb}),{ }^{206} \mathrm{~Pb}, \\
{ }^{207} \mathrm{~Pb},{ }^{208} \mathrm{~Pb},{ }^{232} \mathrm{Th},{ }^{238} \mathrm{U}\end{array}$ \\
\hline Dwell time & $\begin{array}{l}0.2 \mathrm{~s} \text { for }{ }^{206,207,208} \mathrm{~Pb} \\
0.1 \mathrm{~s} \text { for others }\end{array}$ \\
\hline \multicolumn{2}{|l|}{ Standard materials } \\
\hline 91500 & Wiedenbeck et al.(1995) \\
\hline OD-3 & $\begin{array}{l}\text { Iwano et al. (2012), Iwano et al. } \\
\text { (2013), Lukács et al. (2015) }\end{array}$ \\
\hline GJ-1 & Jackson et al. (2004) \\
\hline Plěsovice & Sláma et al. (2008) \\
\hline
\end{tabular}

\subsection{Sample IT01}

This sample contained abundant fine- to medium-sized euhedral zircon grains. Approximately 1,000 grains were extracted from $300 \mathrm{~g}$ of the sample. A total of 26 concordant analyses form a nearly unimodal distribution clustered between 82 and $73 \mathrm{Ma}$ (Fig. 4; Table 3), with three older ages around 96-90 Ma. The generalized ESD test eliminated these older ages as outliers, and 23 grains were therefore accepted for age calculation. The conventional concordia $\left({ }^{207} \mathrm{~Pb} /{ }^{235} \mathrm{U}-{ }^{206} \mathrm{~Pb} /{ }^{238} \mathrm{U}\right)$, Tera-Wasserburg concordia $\left({ }^{238} \mathrm{U} /{ }^{206} \mathrm{~Pb}-{ }^{207} \mathrm{~Pb} /{ }^{206} \mathrm{~Pb}\right)$, and weighted mean ${ }^{206} \mathrm{~Pb} /{ }^{238} \mathrm{U}$ ages and $2 \sigma$ errors are $78.3 \pm 1.3 \mathrm{Ma}, 78.5 \pm$ $1.3 \mathrm{Ma}$, and $78.3 \pm 1.3 \mathrm{Ma}$, respectively (Fig. 4). The weighted mean ${ }^{206} \mathrm{~Pb} /{ }^{238} \mathrm{U}$ age and uncertainties passed the reduced chi-squared test $\left(\chi_{\text {red }}^{2}=0.5\right)$. High Th/U ratios $(0.35-1.00)$ indicate that the zircon grains are igneous in origin (e.g., Hoskin and Schaltegger, 2003).

\subsection{Sample IT02}

Zircon grains in this sample are mostly fine grained and euhedral to subhedral. About 200 zircons were separated from $300 \mathrm{~g}$ of this sample, fewer than from the other samples. Owing to the relatively large analytical errors, 10 of the 30 analyses were discordant (Fig. 5; Table 4). The single-grain ages from IT02 are widely spread, ranging from 73 to $90 \mathrm{Ma}$. The generalized ESD test did not exclude any of the 20 concordant analyses. The accepted data $(n=20)$ yield a conventional concordia age of 80.6 $\pm 1.1 \mathrm{Ma}(2 \sigma)$, a Tera-Wasserburg concordia age of 81.2 $\pm 1.1 \mathrm{Ma}$, and a weighted mean ${ }^{206} \mathrm{~Pb} /{ }^{238} \mathrm{U}$ age of $80.8 \pm$ $1.2 \mathrm{Ma}$ (Fig. 5c). The $\chi_{\text {red }}^{2}$ test for the weighted mean of ${ }^{206} \mathrm{~Pb} /{ }^{238} \mathrm{U}$ ages failed $\left(\chi_{\text {red }}^{2}>1 \pm 2 \sqrt{2 / f}\right)$. The Th/U ratios $(0.37-0.85)$ are similar to those of IT01 and similarly indicate an igneous origin.

\subsection{Sample IT03}

IT03 contains abundant zircons, and about 10,000 grains were obtained from $300 \mathrm{~g}$ of the sample. The zircon crystals are mainly fine to medium grained and show euhedral prismatic shapes. A total of 28 concordant analyses form a single peak around $78 \mathrm{Ma}$, with several older analyses from 240 to $80 \mathrm{Ma}$ (Fig. 6; Table 5). We removed six data points from the age calculations based on the generalized ESD test, leaving 22 analyses. The resultant conventional concordia, Tera-Wasserburg concordia, and weighted mean ${ }^{206} \mathrm{~Pb} /{ }^{238} \mathrm{U}$ ages are $79.3 \pm$ 1.0 Ma, 79.6 $\pm 1.0 \mathrm{Ma}$, and $79.3 \pm 1.1 \mathrm{Ma}$, respectively. The weighted mean ${ }^{206} \mathrm{~Pb} /{ }^{238} \mathrm{U}$ age passed the $\chi_{\text {red }}^{2}$ test $\left(\chi_{\text {red }}^{2}=1.3 ; n=22\right)$. The range of Th/U ratios $(0.42-0.90)$ is similar to those of the other samples.

\section{Discussion}

Samples IT01 and IT03 show unimodal age distributions

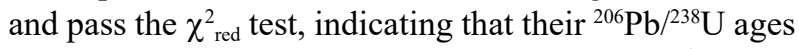
form single statistical populations. These ages (78.3 \pm 1.3 Ma for IT01 and 79.3 $\pm 1.1 \mathrm{Ma}$ for IT03) can be considered to be the maximum depositional ages of the tuff beds from which the samples were taken, and they correspond to the middle Campanian and polarity chron C33n (Ogg et al., 2012). However, the U-Pb ages of sample IT02 are widely spread on a histogram and fail the $\chi_{\text {red }}^{2}$ test. This suggests that the IT02 data could be a mixture of multiple populations or that the analytical uncertainties were underestimated.

One reason that IT02 contains more discordant data ( $n$ $=10$ ) is likely to be the relatively low analytical precision, especially that of ${ }^{207} \mathrm{~Pb}$, possibly because of the smaller size of the zircon crystals and the ablation crator size compared with the other samples (Table 2). Lead loss caused by post-depositional regional metamorphism is considered unlikely, as the concordia plots do not indicate stoichiometric loss of ${ }^{207} \mathrm{~Pb} /{ }^{206} \mathrm{~Pb}$, and only sample IT02 contains a substantial number of discordant analyses. However, zircon grains might have lost $\mathrm{Pb}$ during pre- 

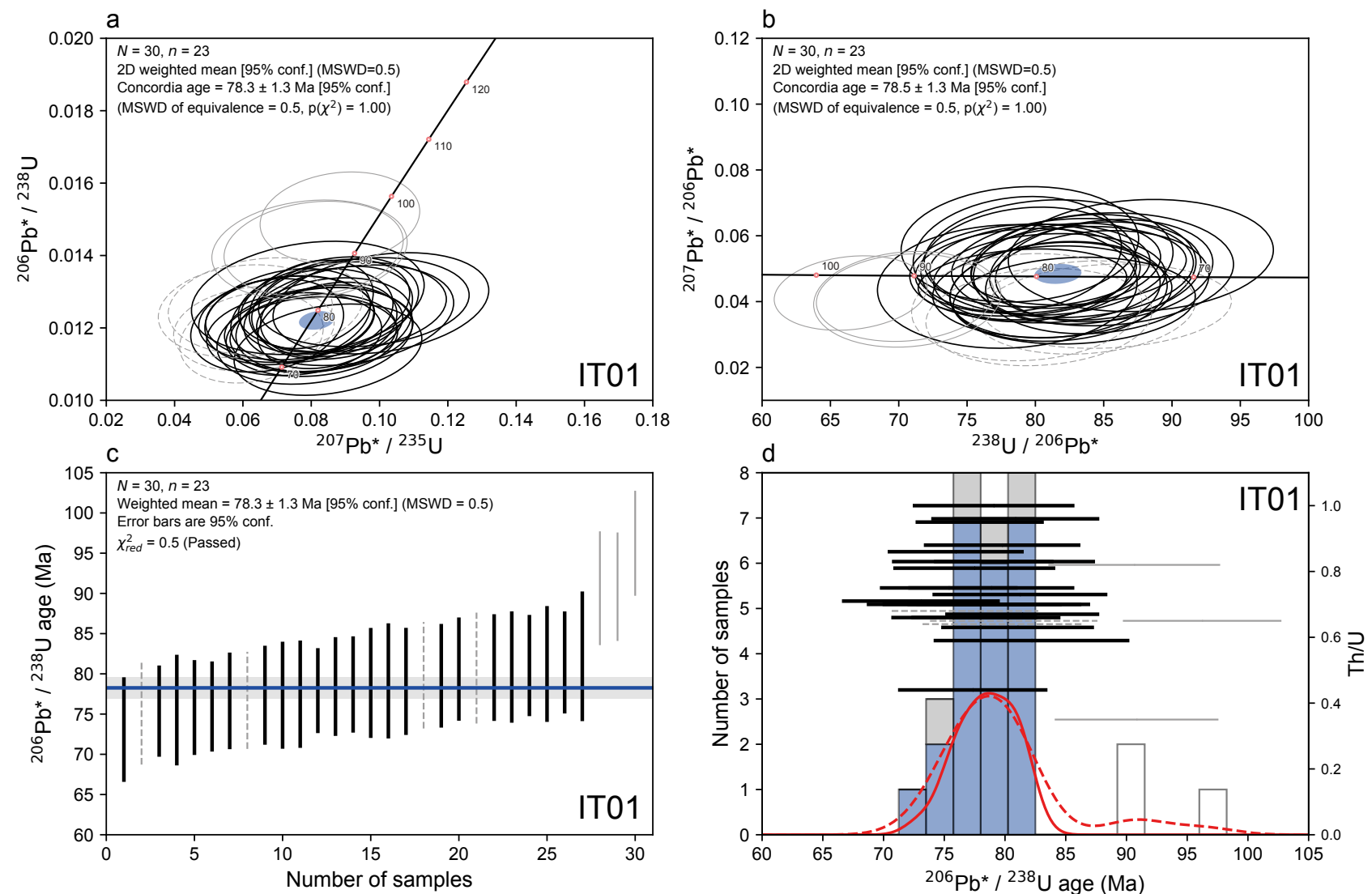

Fig.4 U-Pb dating results for IT01. (a) ${ }^{207} \mathrm{~Pb}^{*} / 235 \mathrm{U}^{206} \mathrm{~Pb}^{*} / 238 \mathrm{U}$ concordia diagram (Wetherill, 1956). Asterisks $(*)$ of ${ }^{206} \mathrm{~Pb}^{*}$ and ${ }^{207} \mathrm{~Pb}^{*}$ denote radiogenic. Solid black, solid gray, and dashed gray ellipses represent $2 \sigma$ errors of accepted, excluded, and discordant data points, respectively. The blue ellipse is the $95 \%$ confidence region of the two-dimensional weighted mean. $N$ and $n$ are numbers of total and accepted grains, respectively. Data exclusion was based on the generalized ESD test (Rosner, 1983) for the weighted mean ${ }^{206} \mathrm{~Pb} /{ }^{238} \mathrm{U}$ age and $2 \sigma$ uncertainties. (b) Tera-Wasserburg concordia diagram (Tera and Wasserburg, 1972). The description is the same as for (a). (c) One-dimensional weighted mean ${ }^{206} \mathrm{~Pb} /{ }^{238} \mathrm{U}$ age (blue line) and its $2 \sigma$ error (gray band). Solid black, solid gray, and dashed gray lines represent accepted, excluded, and discordant data $(2 \sigma)$, respectively. (d) $\mathrm{Th} / \mathrm{U}$ ratios (right-hand axis with horizontal black and gray lines) and stacked ${ }^{206} \mathrm{~Pb} /{ }^{238} \mathrm{U}$ age histograms (left-hand vertical axis), with accepted (blue bars), excluded (white bars), and discordant (gray bars) data. Solid red and dashed red lines represent (kernel density estimation) for accepted $(n=23)$ and all $(n=30)$ data.

depositional metasomatism in the source area. Local fluid alteration in glassy tuff beds is also a possible cause of $\mathrm{Pb}$ loss, although there is no evidence of intrusive rocks or hydrothermal alteration around the sampling site.

The ages obtained during this study are similar to previously reported ages from the lower Takikubo Formation (78.3 $\pm 0.5 \mathrm{Ma}$ for KT01 and $80.8 \pm 0.7 \mathrm{Ma}$ for KT02, Noda et al., 2017b). The age of KT02 may not be reliable, as the data show multiple peaks on a histogram, and the $\chi^{2}$ red statistic $(3.9 ; n=7)$ shows that the data are widely dispersed. Therefore, the maximum depositional ages of the Takikubo and Horita formations range between $79.3 \pm 1.1$ and $78.3 \pm 1.3 \mathrm{Ma}$, based on three accepted samples (KT01, IT01, and IT03; Fig. 7). The U-Pb ages obtained from the Takikubo and the Horita formations show no younging trend according to the stratigraphic position (Fig. 7).
There are three possible interpretations can be regarded for the similar zircon $\mathrm{U}-\mathrm{Pb}$ ages obtained from the different stratigraphic positions, which include (1) a repetition of the same stratigraphic unit by faults, (2) a rapid sedimentation, and (3) an intermittent volcanic activity. As for the first interpretation, an interfingering relationship between the northern marginal facies and the main facies (Fig. 1) indicates that stratigraphically upper sequences progressively deposited eastward, and no large-scale faults can be recognized to stack the same stratigraphic units repeatedly (Matsuura et al., 2002; Noda et al., 2017a). In addition, there is a difference in occurrences of tuff beds in each formation; for example, the upper part of the Takikubo Formation (the Umpenji Sandstone Member) contains fewer tuff beds than the lower part of the Horita Formation (Matsuura et al., 2002; Noda et al., 2017a). This suggests that both formations 


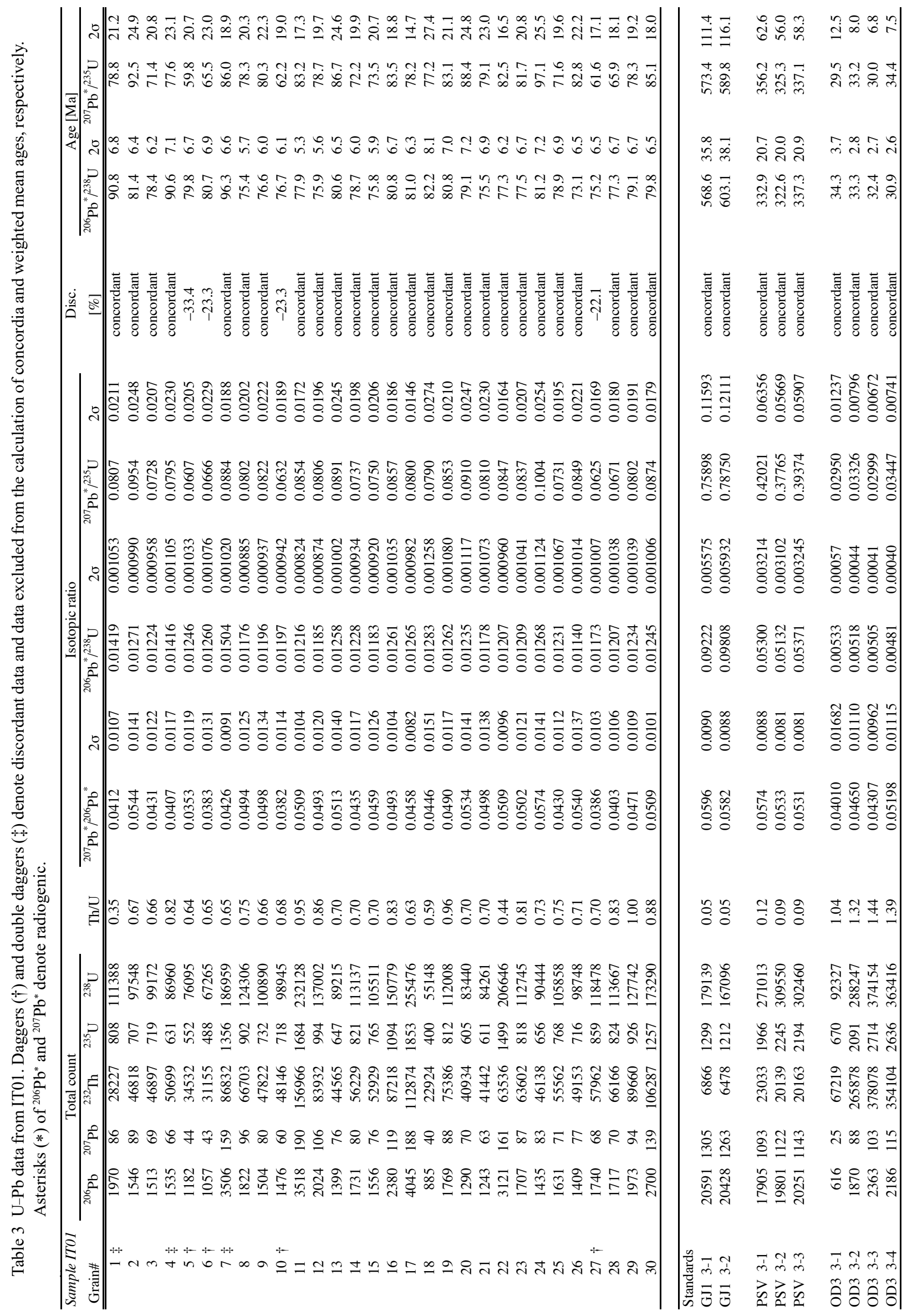



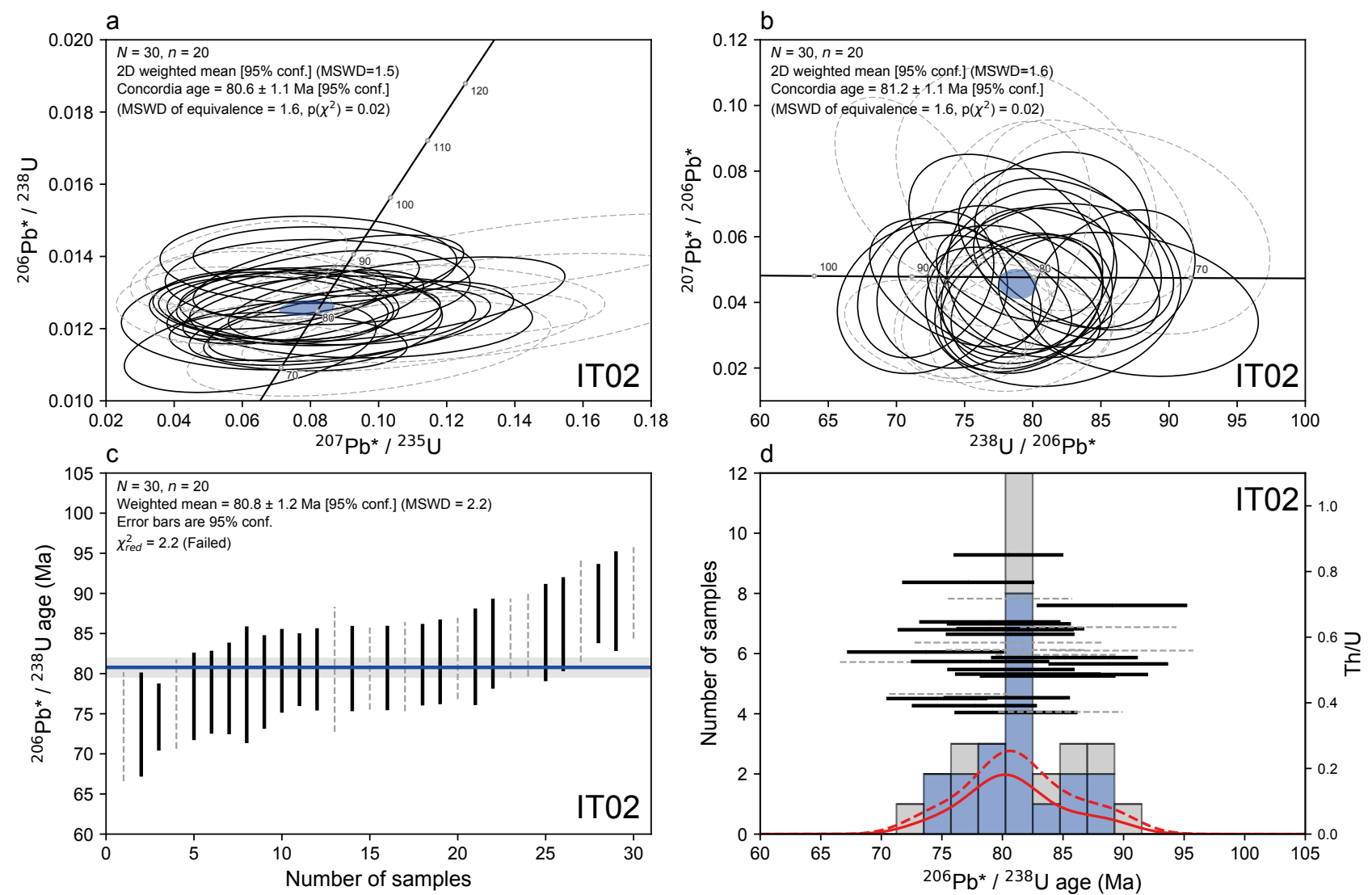

Fig.5 Results of U-Pb dating of IT02. The description is the same as for Fig. 4.

are not identical each other. Therefore, we consider that the tuff beds we analyzed in this study had been obtained from the different sedimentary unit.

Regarding the second interpretation, the Izumi Group in the Ikeda district (the upper Takikubo Formation and the lower Horita Formation) belongs to a single fossil zone, namely, the Metaplacenticeras subtilistriatum Ammonite Zone (Bando and Hashimoto, 1984) or the Archaeodictyomitra lamellicostata Radiolarian Zone (Hashimoto et al., 2015). The fossil and U-Pb data therefore imply that the period of deposition was so short that the fossil assemblage did not change and the deposition rapidly occurred within the range of uncertainties of the U-Pb ages. An apparent total sediment thickness of $12 \mathrm{~km}$ from the lower Takikubo Formation to the lower Horita Formation yields a deposition rate of $3.5 \mathrm{~m} \mathrm{kyr}^{-1}$, if this succession had been deposited between $79.3+1.1$ and $78.3-1.3 \mathrm{Ma}$ (Fig. 7). This rate is higher than the depositional rate in the Kazusa Group (2.0-3.0 $\mathrm{m} \mathrm{kyr}^{-1}$; Kazaoka et al., 2015) and three times higher than that in the Kumano Basin (1.0-1.3 $\mathrm{m} \mathrm{kyr}^{-1}$; Moore et al., 2015). However, this would be possible if intensive igneous flareup events around ca. $80 \mathrm{Ma}$ (Sato et al., 2016b) provided huge amounts of detritus to the basin of the Izumi Group in a short time period.

The third interpretation is that volcanoes in the hinterland that could have produced new zircon crystals were quiescent during the deposition of this succession. Zircon grains in the tuff beds were sourced from the volcanic rocks that were generated before the deposition of the Takikubo Formation. Most of the reported $\mathrm{U}-\mathrm{Pb}$ ages from volcanic rocks in the Sanyo Belt in the Chugoku district are older than $80 \mathrm{Ma}$ (Fig. 1); the youngest is $78.9 \mathrm{Ma}$, from the Ikuno Formation (Sato, 2015). There are no ages younger than 78.9 Ma reported from volcanic rocks except for the Koto Group in the Kinki district (73.5-74.0 Ma; Sato et al., 2016b). Because there is no known volcanic activity between 78 and $74 \mathrm{Ma}$, it is possible that volcanic activity was intermittent and therefore that supply of new zircon crystals was restricted after $78 \mathrm{Ma}$. If so, it would be difficult to determine precise depositional ages and sedimentation rates during this period.

\section{Conclusions}

Zircon U-Pb ages were measured in felsic tuffaceous samples of IT01 (upper Takikubo Formation) and IT02 and IT03 (lower Horita Formation) from the Izumi Group in the Ikeda district, eastern Shikoku. The ${ }^{206} \mathrm{~Pb} /{ }^{238} \mathrm{U}$ ages are $78.3 \pm 1.3 \mathrm{Ma}$ (IT01), $80.8 \pm 1.2 \mathrm{Ma}$ (IT02), and $79.3 \pm 1.1 \mathrm{Ma}$ (IT03). The ages of IT01 and IT03 pass the $\chi_{\text {red }}^{2}$ statistical test and therefore indicate the maximum depositional ages of the tuff beds. The ages of IT01 and IT03 overlap the age previously reported from the lower 

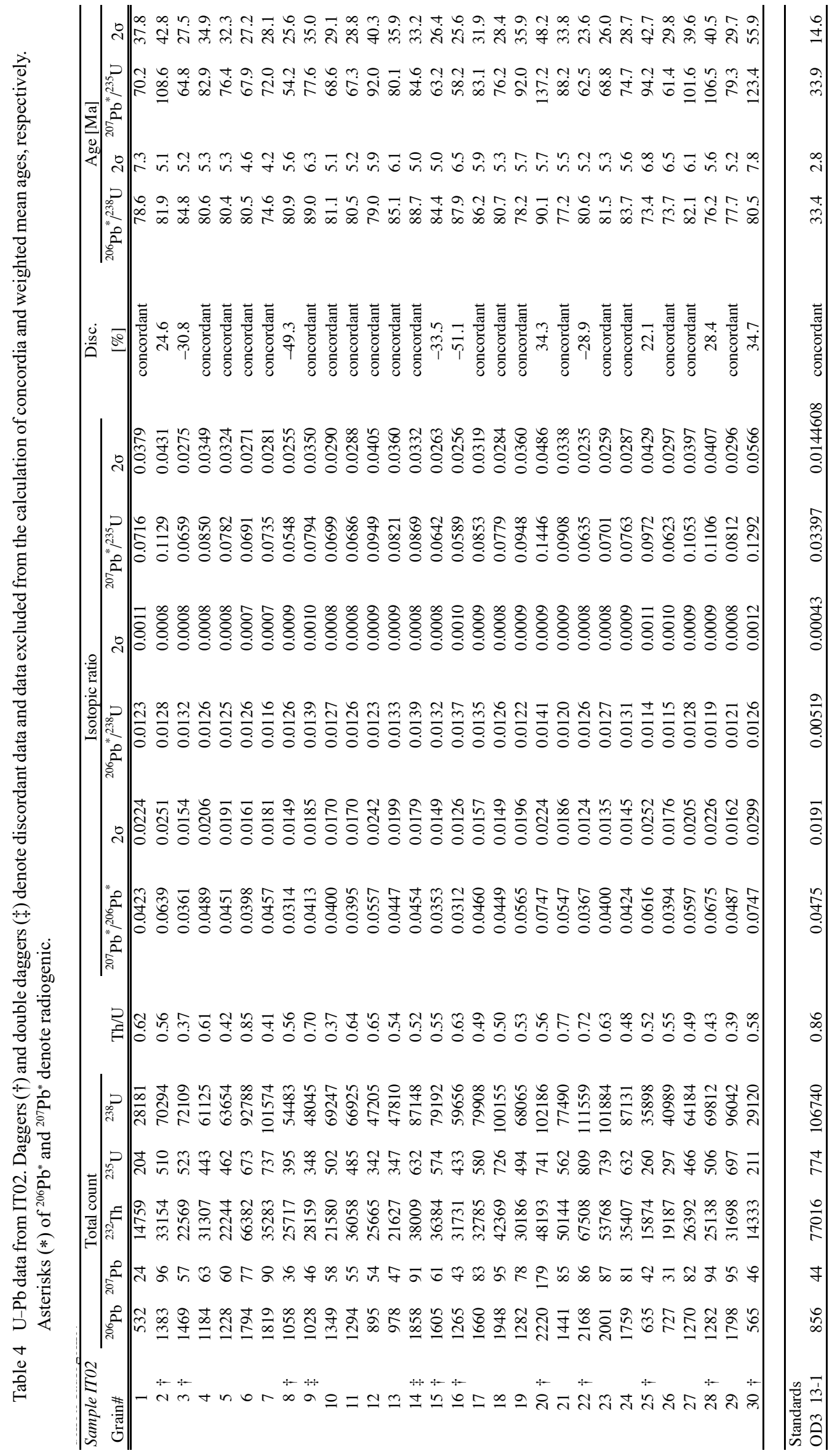

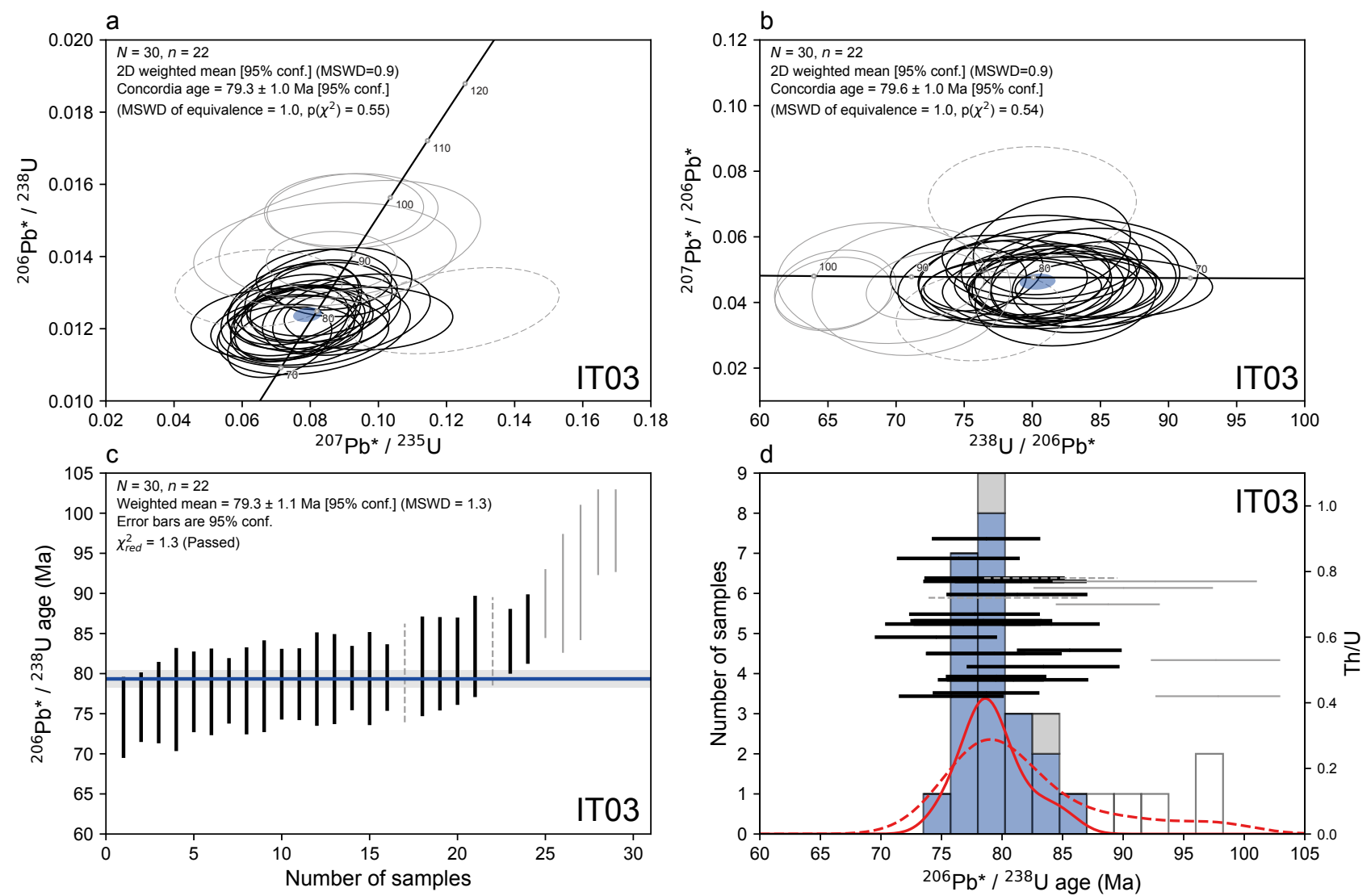

Fig. 6 Results of U-Pb dating of IT03. The description is the same as for Fig. 4. One data point (240.6 Ma) is outside of the plotted region.

Takikubo Formation in the Kan-onji district (KT01: $78.3 \pm 0.5 \mathrm{Ma})$. This suggests that either the deposition occurred over a short period or volcanic activity that produced new zircon crystals in the hinterland (Sanyo Belt) was minimal after $78 \mathrm{Ma}$.

\section{Acknowledgement}

Thin-sections were prepared by Sato Takumi, Owada Akira, Fukuda Kazuyuki and Hirabayashi Eri of the Geoinformation Service Center, National Institute of Advanced Industrial Science and Technology (AIST). This manuscript benefited from thoughtful reviews by Uchino Takayuki. This work is part of study of the quadrangle series, 1:50,000 "Geology of the Ikeda district" conducted by the Geological Survey of Japan, AIST.

\section{Appendix}

The generalized ESD (extreme Studentized deviate) test is a common procedure for detecting outliers in data that follow an approximately normal distribution (Rosner, 1983). This test is essentially an iterative application of the Grubbs rejection test (Grubbs, 1950, 1969; Grubbs and Beck, 1972) for eliminating the maximum or minimum outlier. The test statistic for the $i$ th data point is defined as

$$
R_{i}=\frac{\max _{i}\left|x_{i}-\bar{x}\right|}{\sigma}
$$

where $\bar{\chi}$ is the sample mean and $\sigma$ is the standard deviation. If the maximum $R_{i}$ of the $i$ th element is greater than the critical value at a significance level $\alpha$, then the element is considered to be an outlier. The critical value corresponding to the $i$ th test can be calculated by

$$
\lambda_{i}=\frac{(n-i) t_{p, v}}{\sqrt{(n-i+1)\left(n-i-1+t_{p, v}^{2}\right)}} \quad i=1,2, \ldots, r
$$

where $t_{p, v}$ is the $100 p$ percentage point from the Student's $t$ distribution with $v$ degrees of freedom $(n-i-1)$ and $p=$ $1-\alpha / 2(n-i+1)$. The test repeats by increasing $i$ while $R_{i}>\lambda_{i}$, and then the number of outliers, $r$, is determined by finding the largest $i$ from this procedure.

To consider the $2 \sigma$ uncertainties and the weighted mean, we modify Eq. (A1) to get

$R_{i}= \begin{cases}\frac{\left|\left(x_{i}-2 \sigma_{i}\right)-\mu\right|}{2 \sigma_{w}} & \text { maximum value, when }\left(x_{i}-2 \sigma_{i}\right)>\mu \\ \frac{\left|\left(x_{i}+2 \sigma_{i}\right)-\mu\right|}{2 \sigma_{w}} & \text { minimum value, when }\left(x_{i}+2 \sigma_{i}\right)<\mu\end{cases}$

where $\mu$ and $\sigma_{w}$ are the weighted sample mean and 


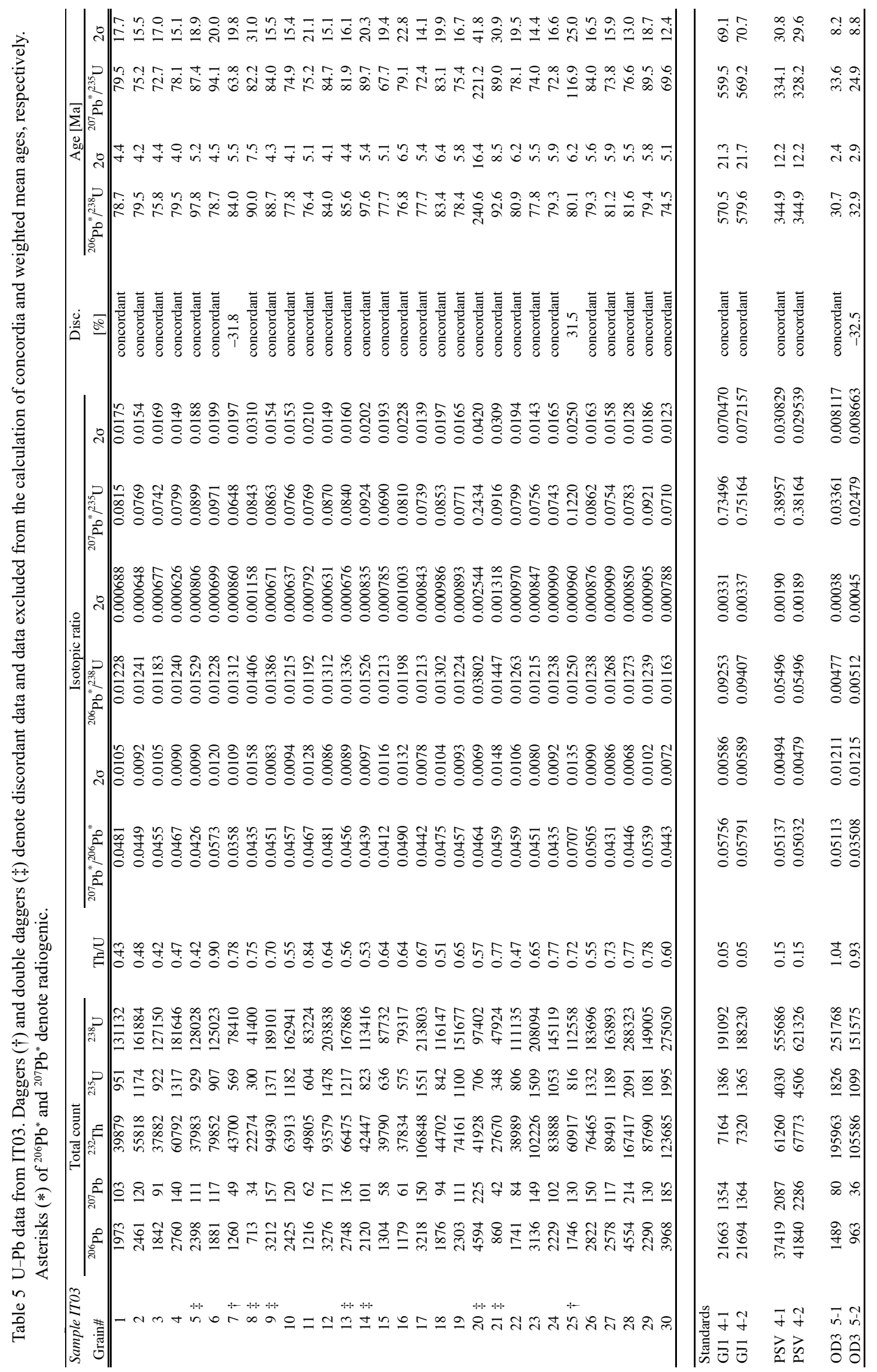




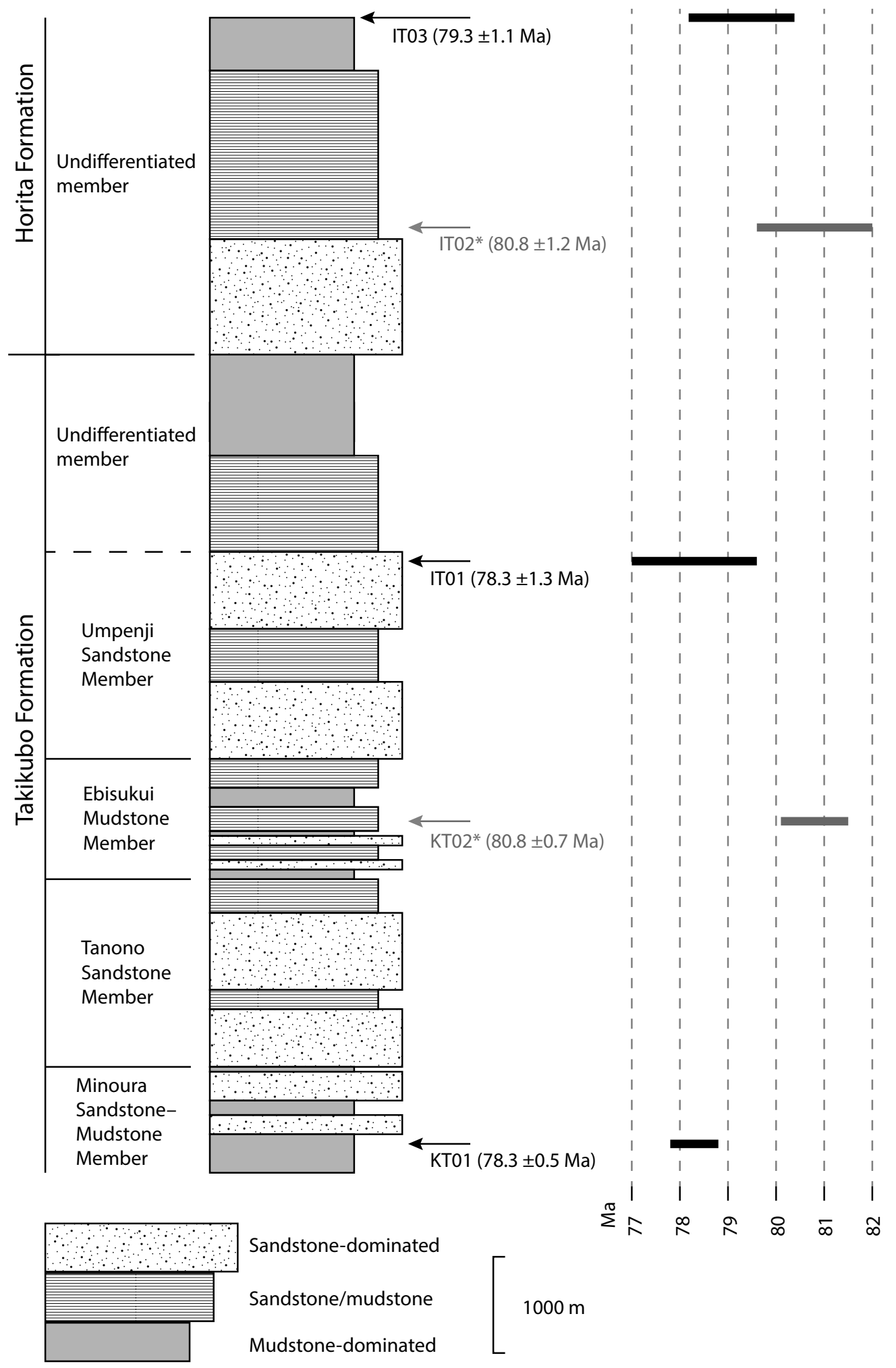

Fig. 7 A generalized stratigraphic column of the main facies from the Kan-onji to Ikeda districts, with the stratigraphic positions of the samples with U-Pb ages. The lithological data are based on Noda et al. (2017a) and Matsuura et al. (2002). U-Pb ages of KT01 and KT02 come from Noda et al. (2017b). Ages with asterisks (*) are rejected data by the $\chi_{\text {red }}^{2}$ statistical test (Spencer et al., 2016). Horizontal bars depict $2 \sigma$ age uncertainties, with black bars and gray bars representing data accepted and rejected by the $\chi_{\text {red }}^{2}$ statistical test, respectively. 
the standard error, respectively. We used 0.05 for the significance level, $\alpha$.

\section{References}

Bando, Y. and Hashimoto, H. (1984) Biostratigraphy and ammonite fauna of the Izumi Group (Late Cretaceous) in the Asan Mountains. Mem. Fac. Educ., Kagawa Univ., II, 34, 1-16 (in Japanese with English abstract).

Geological Survey of Japan, AIST ed., (2015) Seamless digital geological map of Japan 1:200,000, May 29, 2015 version, Geological Survey of Japan, National Institute of Advanced Industrial Science and Technology. Available from: https://gbank.gsj. jp/seamless/index_en.html [Accessed: 2019-07-29].

Grubbs, F. E. (1950) Sample criteria for testing outlying observations. Ann. Math. Stat., 21, 27-58.

Grubbs, F. E. (1969) Procedures for detecting outlying observations in samples. Technometrics, 11, 1-21.

Grubbs, F. E. and Beck, G. (1972) Extension of sample sizes and percentage points for significance tests of outlying observations. Technometrics, 14, 847-854.

Hashimoto, H., Motoyama, S., Ishida, K., Terado, T., Morinaga, H., Nakao, K., Morie, T., Kozai, T., Taisei, O., Fukushima, K. and Kawamura, N. (2003) Geology of the Izumi Group and the Median Tectonic Line in the western Tokushima: Mino-cho district. Comprehensive Research Report of Minocho, Proceedings of Awa Gakkai, no. 49, 1-12 (in Japanese).

Hashimoto, H., Ishida, K., Yamasaki, T., Tsujino, Y. and Kozai, T. (2015) Revised radiolarian zonation of the Upper Cretaceous Izumi inter-arc basin (SW Japan). Rev. Micropaléontol., 58, 29-50.

Hoskin, P. W. O. and Schaltegger, U. (2003) The composition of zircon and igneous and metamorphic petrogenesis. Rev. Mineral. Geochem., 53, 27-62.

Ishida, K., Terado, T., Hashimoto, T., Murata, A., Morinaga, H., Nakao, K. and Morimoto, S. (1993) The Izumi Group and the Median Tectonic Line in the western Asan Mountains: Geology and geompormology in the Miyoshi-cho district, Tokushima Prefecture. Comprehensive Research Report of Miyoshi-cho, Proceedings of the Local Workshop, no. 39, Awa Gakkai, 1-20 (in Japanese).

Iwano, H., Orihashi, Y., Danhara, T., Hirata, T. and Ogasawara, M. (2012) Evaluation of fission-track and $\mathrm{U}-\mathrm{Pb}$ double dating method for identical zircon grains: Using homogeneous zircon grains in Kawamoto Granodiorite in Shimane prefecture, Japan. Jour. Geol. Soc. Japan, 118, 365-375 (in Japanese with English abstract).

Iwano, H., Orihashi, Y., Hirata, T., Ogasawara, M., Danhara, T., Horie, K., Hasebe, N., Sueoka, S., Tamura, A., Hayasaka, Y., Katsube, A., Ito, H., Tani, K., Kimura, J.-I., Chang, Q., Kouchi, Y., Haruta, Y. and Yamamoto, K. (2013) An inter-laboratory evaluation of OD-3 zircon for use as a secondary $\mathrm{U}-\mathrm{Pb}$ dating standard. Island Arc, 22, 382-394.

Jackson, S. E., Pearson, N. J., Griffin, W. L. and Belousova, E. A. (2004) The application of laser ablationinductively coupled plasma-mass spectrometry to in situ U-Pb zircon geochronology. Chem. Geol., 211, 47-69.

Kazaoka, O., Suganuma, Y., Okada, M., Kameo, K., Head, M. J., Yoshida, T., Sugaya, M., Kameyama, S., Ogitsu, I., Nirei, H., Aida, N. and Kumai, H. (2015) Stratigraphy of the Kazusa Group, Boso Peninsula: An expanded and highly-resolved marine sedimentary record from the Lower and Middle Pleistocene of central Japan. Quat. Int., 383, 116-135.

Lukács, R., Harangi, S., Bachmann, O., Guillong, M., Danišík, M., Buret, Y., von Quadt, A., Dunkl, I., Fodor, L., Sliwinski, J., Soós, I. and Szepesi, J. (2015) Zircon geochronology and geochemistry to constrain the youngest eruption events and magma evolution of the Mid-Miocene ignimbrite flare-up in the Pannonian Basin, eastern central Europe. Contrib. Mineral. Petrol., 170, 52, doi: 10.1007/s00410-015-1206-8.

Matsumoto, T. (1954) The Izumi Belt along the southern border of the Inner Zone of Southwest Japan. In The Cretaceous Research Committee ed., The Cretaceous System in the Japanese Island, Japanese Society for the Promotion of Scientific Research, Ch. IV, 125-137.

Matsuura, H., Kurimoto, C., Yoshida, F., Saito, Y., Makimoto, H., Toshimitsu, S., Iwaya, T., Komazawa, M. and Hiroshima, T. (2002) Geological Map of Japan 1:200,000, Okayama and Marugame. Geological Survey of Japan, AIST.

Miyata, T. (2004) Geology of the Kokawa district, Ch. 5, The Upper Cretaceous Izumi Group. Quadrangle Series, 1:50,000, Geological Survey of Japan, AIST, 28-40 (in Japanese).

Moore, G. F., Boston, B. B., Strasser, M., Underwood, M. B. and Ratliff, R. A. (2015) Evolution of tectonosedimentary systems in the Kumano Basin, Nankai Trough forearc. Mar. Petrol. Geol., 67, 604-616.

Nakano, M. (1953) On the Izumi Group of the Central part of the Sanuki Mountain-Range, Japan. Geol. Rep. Hiroshima Univ., 3, 1-13 (in Japanese with English abstract).

Nishimura, T. (1976) Petrography of the Izumi sandstone in the east of the Sanuki Mountain Range, Shikoku, Japan. Jour. Geol. Soc. Japan, 82, 231-240.

Nishiura, M., Yamasaki, T. and Okumura, K. (1993) Sedimentary structure of the Izumi Group developed in the western part of the Asan Range, Shikoku, Japan. Jour. Sediment. Soc. Japan, 38, 33-44 (in Japanese with English abstract).

Noda, A. (2017) A new tool for calculation and visualization of $\mathrm{U}-\mathrm{Pb}$ age data: UPbplot.py. Bull. Geol. Surv. Japan, 68, 131-140.

Noda, A. and Sato, D. (2018) Submarine slope-fan 
sedimentation in an ancient forearc related to contemporaneous magmatism: The Upper Cretaceous Izumi Group, southwestern Japan. Island Arc, 27, e12240.

Noda, A. and Toshimitsu, S. (2009) Backward stacking of submarine channel-fan successions controlled by strike-slip faulting: The Izumi Group (Cretaceous), southwest Japan. Lithosphere, 1, 41-59.

Noda, A., Ueki, T., Kawabata, H., Matsuura, H. and Aoya, M. (2017a) Geology of Kan-onji district, Quadrangle Series, 1:50,000, Geological Survey of Japan, AIST, 96p. (in Japanese with English abstract).

Noda, A., Danhara, T., Iwano, H. and Hirata, T. (2017b) LA-ICP-MS U-Pb and fission-track ages of felsic tuff beds of the Takikubo Formation, Izumi Group in the Kan-onji district, eastern Shikoku, southwestern Japan. Bull. Geol. Surv. Japan, 68, 119-130.

Ogg, J. G., Hinnov, L. A. and Huang, C. (2012) Ch. 27, Cretaceous. In Gradstein, F. M., Ogg, J. G., Schmitz, M. D., and Ogg, G. M. eds., The Geologic Time Scale, Elsevier, 793-853.

Rosner, B. (1983) Percentage points for a generalized ESD many-outlier procedure. Technometrics, 25, 165-172.

Sato, D. (2015) U-Pb zircon dating of the Late Cretaceous volcanic rocks from the Ikuno and Mitsuishi mines area, southwest Japan. Abstract of the Japan Geoscience Union Meeting, SCG58-P09.

Sato, D. (2016) Zircon U-Pb and fission-track ages of Late Cretaceous volcanic rocks of the Ieshima Islands, southwest Japan. Japan. Mag. Mineral. Petrol. Sci., 45, 53-61 (in Japanese with English abstract).

Sato, D., Yamamoto, T. and Takagi, T. (2016a) Geology of the Banshu-Ako district. Quadrangle Series, 1:50,000, Geological Survey of Japan, AIST (in Japanese with English abstract).

Sato, D., Matsuura, H. and Yamamoto, T. (2016b) Timing of the Late Cretaceous ignimbrite flare-up at the eastern margin of the Eurasian Plate: New zircon $\mathrm{U}-\mathrm{Pb}$ ages from the Aioi-Arima-Koto region of SW Japan. Jour. Volcanol. Geotherm. Res., 310, 89-97.

Seike, K., Iwano, H., Danhara, T. and Hirano, H. (2013) Tectonics of the Ryoke-Izumi belt of the Izumi Mountains, Southwest Japan from thermochronological data. Jour. Geol. Soc. Japan, 119, 759-775 (in Japanese with English abstract).

Sláma, J., Košler, J., Condon, D. J., Crowley, J. L., Gerdes, A., Hanchar, J. M., Horstwood, M. S. A., Morris, G. A., Nasdala, L., Norberg, N., Schaltegger, U., Schoene, B., Tubrett, M. N. and Whitehouse, M. J. (2008) Plešovice zircon -A new natural reference material for $\mathrm{U}-\mathrm{Pb}$ and $\mathrm{Hf}$ isotopic microanalysis. Chem. Geol., 249, 1-35.
Spencer, C. J., Kirkland, C. L. and Taylor, R. J. M. (2016) Strategies towards statistically robust interpretations of in situ U-Pb zircon geochronology. Geosci. Frontiers, 7, 581-589.

Suyari, K. (1966) Studies of the Izumi Group in the Eastern Asan Mountain Rage, Shikoku (I). Jour. Sci., Coll. Gen. Educ., Univ. Tokushima, 1, 9-14 (in Japanese with English abstract).

Suyari, K. (1973) On the lithofacies and the correlation of the Izumi Group of the Asan Mountain Range, Shikoku. Sci. Rep. Tohoku Univ., 2nd Series, (Geology), Special Volume, 6, 489-495 (in Japanese with English abstract).

Suyari, K., Odoi, Y., Kume, Y., Kondo, K., Toake, S., Sobue, K., Terado, T. and Bando, H. (1968) Studies of the Izumi Group in the Eastern Asan Mountain Rage, Shikoku (II). Jour. Sci., Coll. Gen. Educ., Univ. Tokushima, 2, 7-16 (in Japanese with English abstract).

Tanaka, J. (1993) Sedimentation and tectonics in the Cretaceous, strike-slip Izumi basin, Izumi mountains, Japan. Jour. Geosci., Osaka City Univ., 36, 85-107.

Tanaka, J. and Maejima, W. (1995) Fan-delta sedimentation on the basin margin slope of the Cretaceous, strikeslip Izumi Basin, southwestern Japan. Sediment. Geol., 98, 205-213.

Tera, F. and Wasserburg, G. J. (1972) U-Th-Pb systematics in three Apollo 14 basalts and the problem of initial $\mathrm{Pb}$ in lunar rocks. Earth Planet. Sci. Lett., 14, 281-304.

Wendt, I. and Carl, C. (1991) The statistical distribution of the mean squared weighted deviation. Chem. Geol.: Isotope Geosci. Sec., 86, 275-285.

Wetherill, G. W. (1956) Discordant uranium-lead ages, I. Eos, Trans. Am. Geophys. Union, 37, 320-326.

Wiedenbeck, M., Allé, P., Corfu, F., Griffin, W. L., Meier, M., Oberli, F., Quadt, A. V., Roddick, J. C. and Spiegel, W. (1995) Three natural zircon standards for $\mathrm{U}-\mathrm{Th}-\mathrm{Pb}$, Lu-Hf, trace element and REE analyses. Geostandards Newsletter, 19, 1-23.

Yamasaki, T. (1986) Sedimentological study of the Izumi Group in the northern part of Shikoku, Japan. Sci. Rep. Tohoku Univ., 2nd Series, Geology, 56, 43-70.

Yamasaki, T. (1987) Radiolarian assemblages of the Izumi Group in Shikoku and western Awaji Island, Southwest Japan. Jour. Geol. Soc. Japan, 93, 403-417 (in Japanese with English abstract).

Yokoyama, K. and Goto, A. (2000) Petrological study of the Upper Cretaceous sandstones in the Izumi Group, Southwest Japan. Mem. Natl. Sci. Mus., Tokyo, 32, $7-17$.

Recieved August 5, 2019

Accepted November 8, 2019 


\section{四国東部の池田地域における和泉層群滝久保層と堀田層の 珪長質凝灰岩の LA-ICP-MS ジルコン U-Pb 年代}

\section{野田＼cjkstart篤・檀原 徹・岩野 英樹・平田 岳史}

\section{要 旨}

四国東部の池田地域に分布する和泉層群の滝久保層と堀田層の堆積年代を制約するために，挟在する珪長質な凝灰質 岩に含まれるジルコン粒子のLA-ICP-MS U-Pb年代を測定した。測定にあたり，滝久保層の上部から1試料 (IT01），堀田 層の下部から2試料 (IT02とIT03) を採取した。測定によって求められた ${ }^{206} \mathrm{~Pb} / 238 \mathrm{U}$ 年代とその誤差 $(2 \sigma)$ は, IT01が78.3

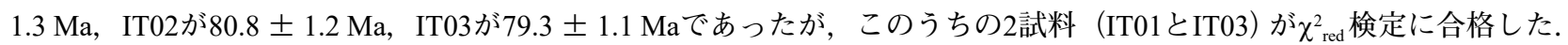
検定に合格した 2 試料が示すU-Pb年代は，採取した凝灰岩の堆積年代の下限を規制し，それは中期カンパニアン期 (古地 磁気年代層序区分のchron C33n）に相当する。これらの年代值は，西隣の観音寺地域から報告されている潼久保層下部の

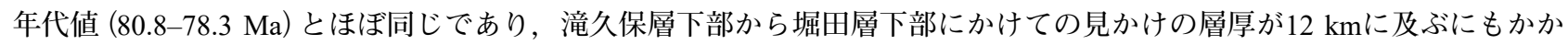
わらず，ジルコンのU-Pb年代值は層序的下位から上位にかけて若くなっていく傾向を見せていない. この理由として， 和泉層群の当時の堆積速度が非常に大きかったこと, または若いジルコン結晶を生成・供給する火成活動が後背地に扔い て一時的に不活発となっていたことが考えられる. 